\title{
SPECIFIC ENERGY OF HARD COAL UNDER LOAD
}

\author{
ANNA Bogusz, MirosŁaWA BUKOWSKA \\ Central Mining Institute, plac Gwarków 1, 40-166 Katowice, \\ correspondence address: abogusz@gig.eu
}

\begin{abstract}
The article presents results of experimental tests of energy parameters of hard coals under loading, collected from research sites located within five main geologic structures of Upper Silesian Coal Basin (GZW) - Main Trough, Main Anticline, Bytom Trough, Rybnik Trough and Chwałowice Trough. Coals from 12 mines were analysed, starting with seams of group 200, through groups 400, 500, 600 and, finally, seams of group 700. Coal of each of the groups of seams underwent uniaxial compression stress of the energy parameters, in a servo-controlled testing machine MTS-810NEW, for the full range of strain of the tested coal samples. Based on the tests the dependence of different types of specific energy of longitudinal strain of coals on the value of uniaxial compression strength was determined. The dependence of the value of dissipated energy and kinetic energy of coals on the uniaxial compression strength was described with a linear function, both for coals which due to their age belong to various bed sand for various lithotypes of coal. An increase in the value of dissipated energy and in kinetic energy was observed, which was correlated with an increase in uniaxial compression strength of coal. The share of dissipated energy is dominant in the total energy of strain. Share of recoverable energy in the total energy of strain is small, independent of the compression strength of coals and is at most a few per cent high. In coals of low strength and dominant share of dissipated energy, share of recoverable energy is the biggest among the tested coals. It was shown that following an increase in compression strength the share of recoverable energy decreases, while the share of dissipated energy in the total energy increases. Further studies of specific energy of longitudinal strain of rocks in the full-range strain will be the next step inperfecting methodology of research into natural rock burst susceptibility of Carboniferous rock mass and changes in the susceptibility resulting from mining activity.
\end{abstract}

Key words: hard coal, specific energy of strain in coal, dissipated energy, kinetic energy, recoverable energy

\section{INTRODUCTION}

Tests of energy parameters of rocks are associated with a process of destroying a rock sample in a testing machine. Stress-strain characteristics resulting from the course of destroying a rock sample, in the conditions of uniaxial or conventional triaxial compression, enables determining geomechanical and energy parameters. Analyses of geomechanical parameters have been researched both in Poland and abroad and refer to sedimentary rocks, as well as igneous rocks and metamorphic rocks. Tests of energy parameters, especially the ones obtained in the full-range of deformation of rock samples, are not so common hence their academic and practical significance, especially in solving engineering problems in mining and geoengineering. For instance, research into phenomena of dynamic destruction of rock mass resulting from mining activities enables assessing probability of occurrence of certain natural hazards in mine workings.

\section{COMPLETE STRESS-STRAIN CHARACTERISTICS OF ROCKS SAMPLES}

The process of destroying rocks subjected to loading in testing machines is illustrated with stress-strain characteristics of rocks. Interpretation of full-range stressstrain characteristics enables determination of the values of stress, recoverable energy, strain and energy parameters. The 1970s started a new era in the area of rock mechanics. Hitherto tests conducted in so-called "soft" testing machines enabled obtaining the rising part of stress-strain characteristics. Bieniawski's experience and numerous research [1] conducted in servo-controlled testing machines enabled obtaining full-range stressstrain characteristics of a compressed rock sample.

Recoverable energy characteristics obtained in tests of rock samples in a servo-controlled testing machine is non-linear and consists of a rising part and a descending part [1]. The rising part of stress-strain characteristics represents the pre-critical phase, with 


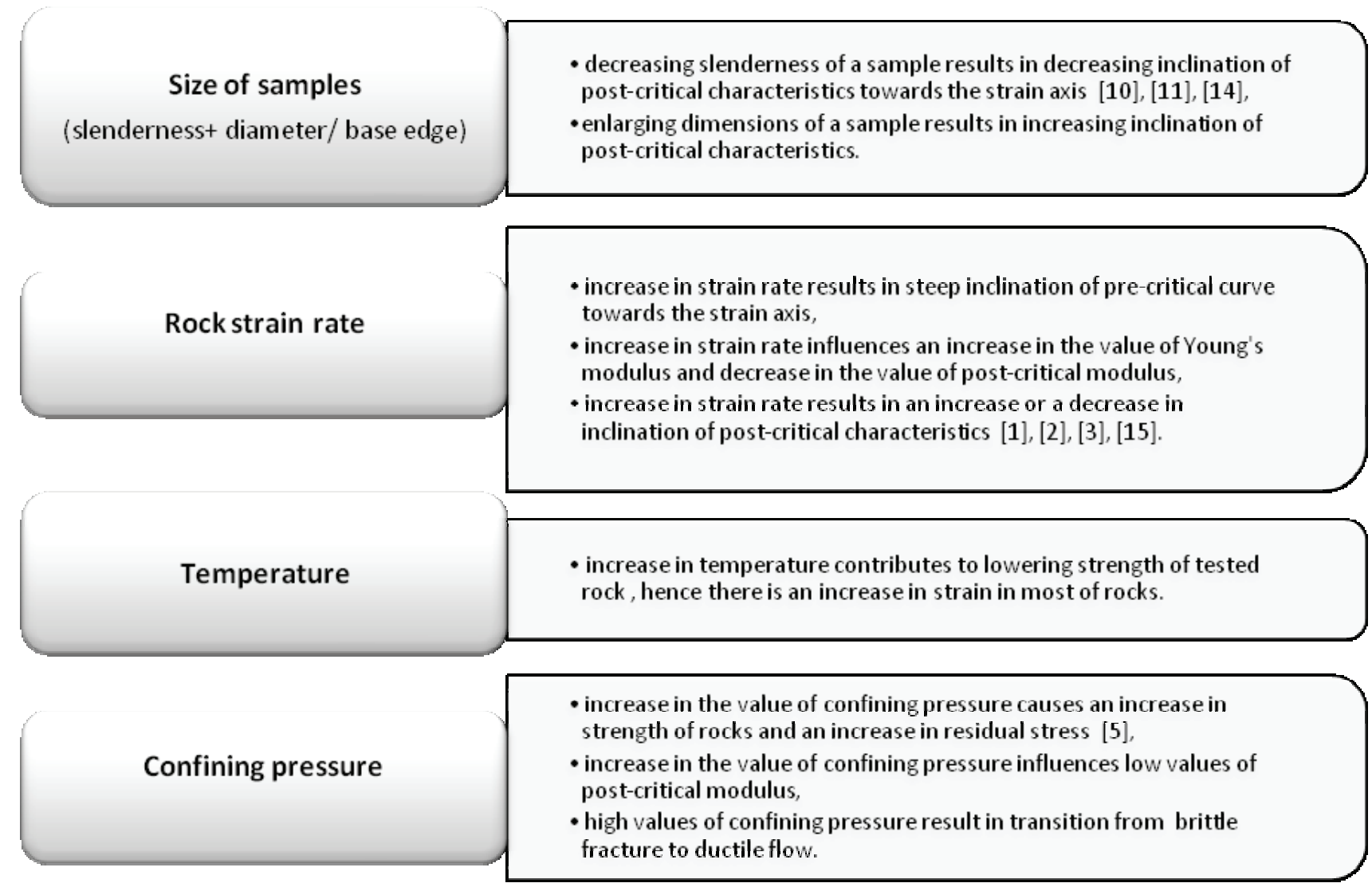

Fig. 1. Influence the most important factors on the shape of stress-strain characteristics

a characteristic increase in stress and strain, until the maximum value of stress is reached for the compressed sample. The descending part of the stressstrain characteristics represents the post-critical phase, in which there is a decrease in stress, until the value of residual stress is reached. In the post-critical part, a decrease ins tress refers to an increase in the value of strain, until the value of residual strain is reached.

Nonlinearity of rock deformation forces a linear approximation of the stress-strain characteristics, both in the pre-critical part, and in post-critical one, to facilitate mathematical description of the course of destroying a loaded rock sample and determine values of geomechanical and energy parameters [8], [16].

Numerous research into strength, elasticity and plasticity of rocks subjected to uniaxial and triaxial compression (axially-symmetric strain state) enabled distinguishing a few stages of strain in rocks in the pre-critical part of stress-strain characteristics. Most of ten the pre-critical part of stress-strain characteristics is divided into three parts. A much more complex division is also used. It was defined based on the results of tests conducted under axially-symmetric strain, concerning longitudinal, transverse and volumetric strain [13].
Depending on the way of destroying rocks resulting from their loading, Wawersik and Fairhurst (1970) divided the post-critical part of stress-strain characteristics into two classes. Class I corresponds to static propagation of cracks in rock once the critical stress is exceeded. Class II corresponds to the phenomenon in which the destruction process continues on its own until the sample loses strength. The shape of stress-strain characteristics obtained during tests in servo-controlled testing machines of high stiffness depends on many factors. Some of them are presented in Fig. 1.

The basis to determine energy parameters is an area limited with the course of a recoverable energy curve and the strain axis. The most important energy parameters, which can be determined based on stressstrain characteristics obtained in the process of loading a rock sample, include:

- specific energy of elastic deformation and specific energy of irreversible deformation (the pre-critical part of the curve); their total is energy of precritical destruction of a sample,

- energy of post-critical destruction with recoverable energy of deformation [9],

- dissipated energy of deformation. 


\section{SPECIFIC ENERGY \\ OF LONGITUDINAL STRAIN OF COALS}

\subsection{DISSIPATED ENERGY \\ AND RECOVERABLE ENERGY OF DEFORMATION OF A LOADED SAMPLE}

Research conducted by Gustkiewicz [6], [7], Heasley [9], Bukowska [3] and Krzysztoń et al. [12] enhanced our knowledge of methods which can be used to determine energy parameters of a rock sample based on the phenomenon of destroying rocks in a servo-controlled testing machine. A rock sample is destroyed when energy from the testing machine (external load), at the post-critical stage, exceeds energy of post-critical plastic deformation. Value of specific energy of longitudinal strain consists of the value of elastic and irreversible deformation energy in the precritical part and energy of post-critical deformation of a sample.

Graphical division of the total energy of deformation for the stress-strain characteristics of coal of elastoplastic properties with softening is presented in Fig. 2.

It was assumed that:

- when coal is loaded beyond the point of maximum stress (point B) to the residual stress part of the characteristics ( $\mathrm{DD}^{\prime}$ line), then unloading coal occurs along $\mathrm{DF}$ line parallel to $\mathrm{AB}$;
- recoverable energy of deformation at point $\mathrm{D}$ equals area DFG, whilst the total energy (work) equals area $0 \mathrm{BDG}$;

- the difference between the total energy and recoverable energy (area 0BDF) is dissipated energy (1), as it is conveyed to the surrounding.

$$
E_{d y s}=W_{1}+W_{2}-W_{3}
$$

where

$W_{1}$ - energy necessary to reach strength limit $\left(W_{1}=A_{n}+A_{s p}\right)$,

$W_{2}$ - energy of post-critical destruction,

$W_{3}$ - recoverable energy.

Knowledge of the value of dissipated energy of rocks is important, as it plays an important role in destroying the structure of rocks, including coal, which, through lowering the strength, leads to their complete destruction [17].

\subsection{KINETIC ENERGY OF COAL OF ELASTOPLASTIC PROPERTIES WITH SOFTENING}

Disintegration of coal, once having exceeded the strength may be a result of the value of accumulated potential elastic energy when the sample cracked. Shear strain energy is used to over come toughness of coal, while volumetric strain energy transforms into

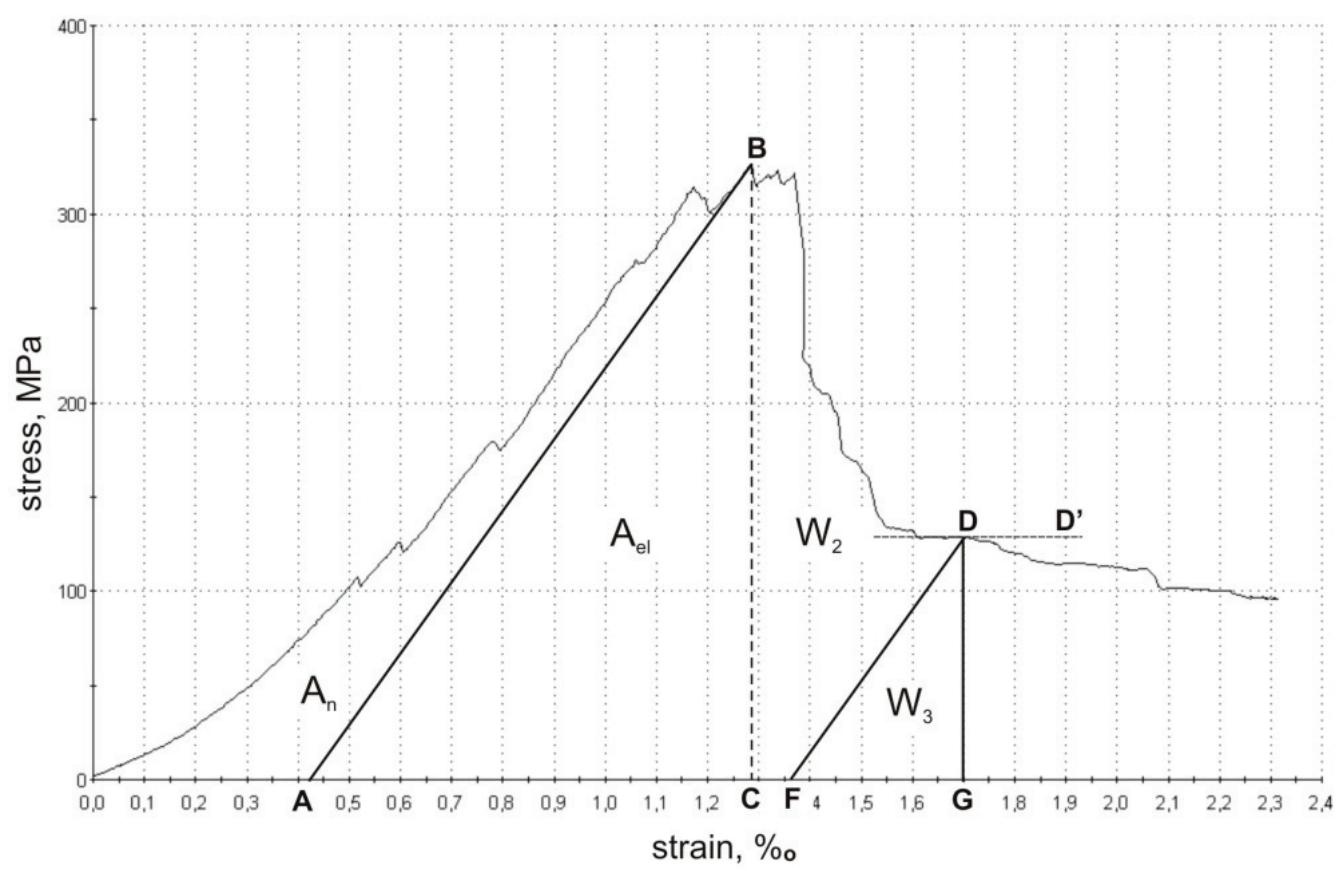

Fig. 2. Image of division of total energy of deformation of a loaded sample (own work) 
kinetic energy, which determines character of coal destruction. Based on the equation of energy balance, the value of kinetic energy was calculated, assuming linear dependence of pre-critical recoverable energy part and post-critical part of the stress-strain characteristics according to (2) [4].

$$
E_{k}=A_{e l}-W_{2}+W_{3}
$$

where

$A_{e l}$ - elastic energy,

$W_{2}$ - energy of post-critical destruction,

$W_{3}$ - recoverable energy of deformation.

\subsection{MINING PRACTICE \\ CONCERNING DETERMINATION \\ OF DISSIPATED ENERGY \\ AND RECOVERABLE ENERGY \\ OF DEFORMATION OF COALS, AS ROCKS \\ OF ELASTOPLASTIC PROPERTIES WITH SOFTENING}

Research conducted by the U.S. Bureau of Mines shoved that the best indicator of rock burst hazard is dissipated energy of deformation of coal, as elastoplastic rocks with softening [9]. An increase in the value of dissipated energy suggests further going destruction of coal and an increase in its flexibility. It influences a change in properties of rocks, including coal. Recoverable energy of deformation is elastic energy. Its value depends on stress in the mined part of a seam [9]. Changes in the value of deformation energy are caused in the rock mass by mining activi-

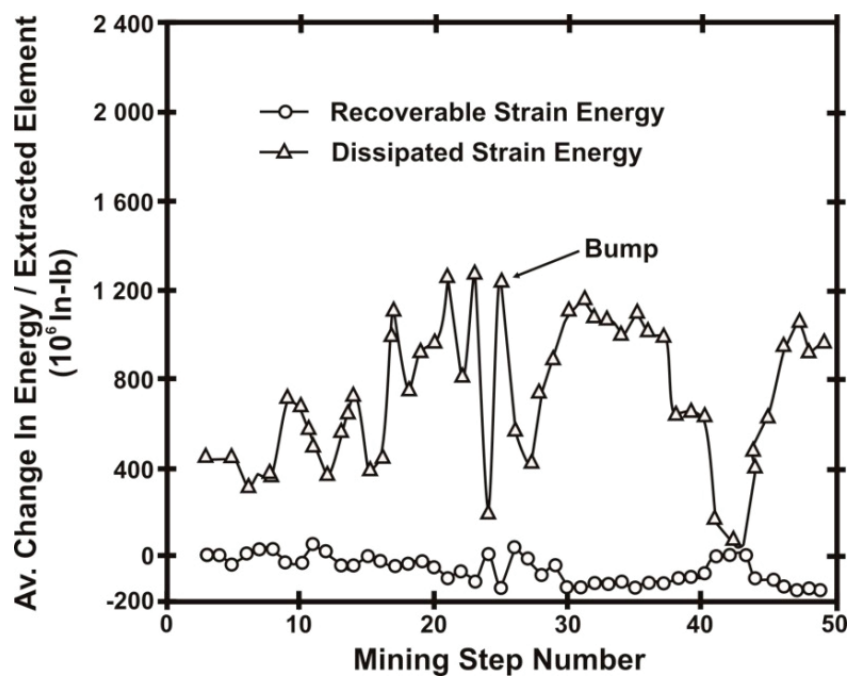

Fig. 3. Changes in values of energy of deformation for mining a barrier pillar [9] ties within given parts of a seam. Observations of the changes may be a good indicator to forecast occurrence of geodynamic phenomena in the rock mass, e.g., rock bursts. Figure 3 presents the results of numerical modeling of the energy of deformation for selected stages of mining a barrier pillar [9]. Based on in situ tests and numerical modeling it was shown that the highest values of dissipated energy of deformation preceded occurrence of a rock burst, which occurred in the area of high stress. In the area the value of recoverable energy of deformation was also higher, and transformed into kinetic energy could result in a rock burst.

\subsection{ANALYSIS OF THE OBTAINED RESULTS OF TESTS OF ENERGY PARAMETERS OF CARBONIFEROUS COALS IN GZW}

The mining area of GZW, where energy parameters were analysed, is located in the area of five main geological structures - Main Anticline and Main Trough, Bytom Trough, Rybnik Trough and Chwałowice Trough. These are mainly areas of fold and block-fold disjunctive tectonics. Coals of 12 coal mines were thoroughly interpreted, considering three main types of lithotypes of hard coal - vitrain, clarain anddurain, starting with group 200, through group $400,500,600$, to finish with seams of group 700 .

The results of research into the energy properties of the coals presented in this paper were obtained from tests conducted using a servo-controlled testing machine, the MTS-810. The tests included uniaxial compression test of $50 \times 50 \times 50 \mathrm{~mm}$ cubic samples. The samples were compressed perpendicular to bedding. Control of the testing machine was performed via the longitudinal strain rate measured in the system of the press with the stroke of the piston. The tests were conducted at strain rates of about $0.005 \mathrm{~mm} / \mathrm{s}$. The results of laboratory tests of 205 samples in the test laboratory uniaxial compression were obtained.

Among hard coals four main lithotypes can be distinguished: vitrain, clarain, durain and fusain. The focus was on the three first lithotypes of hard coal, as fusain occurs in coal seams in the form of inter layers and inclusions in vitrain and clarain.

Properties of given coals depend on the content of various macerals (microscopic components of coal), mainly vitrinite, liptinite and inertinite and the content and type of their natural associations, i.e., microlithotypes. In the further part of the article and in Photos 1-3 typical petrographic composition characteristic 
for given lithotypes of hard coal is presented. Photo 1 shows a sample of clarain of high content of vitrinite ( $75 \%$ share), and relatively low share of liptinite $(5 \%)$, inertinite $(15 \%)$ and minerals (5\%). High share of macerals of vitrinite group in a sample is a result of a high share of vitrite $(62 \%)$ in the composition of microlithotypes. Apart from vitrite there is a high share of clarodurite $(10 \%)$ and duroclarite $(11 \%)$, while there is only a few per cent share of each of the other microlithotypes. Photo 2 shows microscopic image of a sample of vitrain. Among the observed macerals in the testes coal macerals of vitrinite group $(62 \%)$ are dominant.Liptinitehas $11 \%$, andinertinite $20 \%$ share. Duroclarite $(52 \%)$ makes up over half of the composition of the microlithotypes, with significant content of vitrite (18\%) and inertite (12\%).

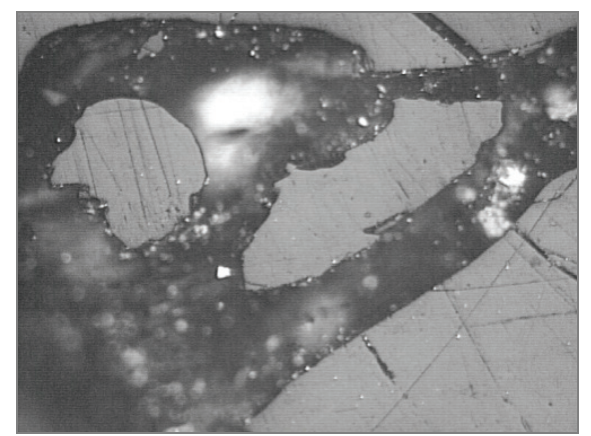

Photo 1. Vitrite with weathering cracks. Cracks partially filled with pyrite

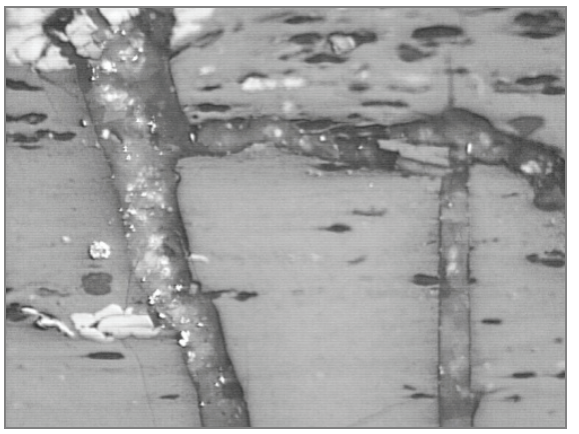

Photo 2. Clarite built of liptinite (sporinite - darkest fragments) in vitrinite (grey). Cracks filled with coarse-crystalline carbonates

Photo 3 shows microscopic image of a sample of durain/vitrain with strips of clarain. In the tested coal similar content of vitrinite (44\%) and inertinite (40\%) can be observed. Share of liptinite (14\%) is also significant. High content of inertinite in the sample, with a significant share of liptinite results from the composition of main microlithotypes. Moreover a high share of duroclarite $(41 \%)$ and clarodurite $(25 \%)$ can be observed together with vitrinertite (14\%), with a high share of inertinite. vitrite, inertite, clarite, durite and vitrinertoliptite have insignificant share (between 1 and a few per cent).

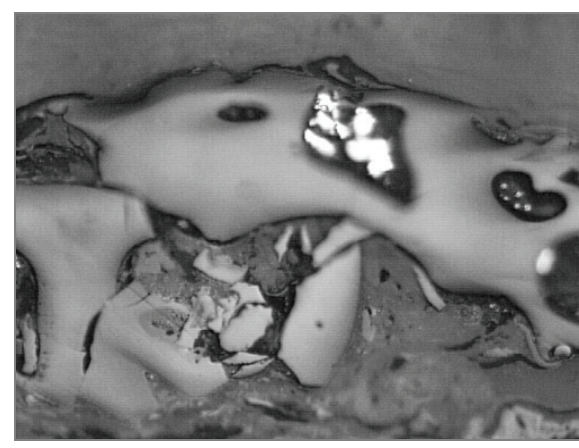

Photo 3. Inertinite (funginite - light fragment) with pyrite

Tests conducted at the Central Mining Institute to determine dissipated, recoverable energy of deformation of coals and kinetic energy were aimed at recognizing the discussed phenomenon better and checking possibilities of using the obtained results in mining practice, e.g., in analyses of the occurrence of rock bursts. Three main lithotypes of coal were analysed: clarain, vitrain and durainas well as values of dissipated energy, kinetic energy and recoverable energy.

Based on the test data obtained (Table 1), values of dissipated energy of coals $\left(E_{d y s}\right)$ were calculated with equation (1), defining also the form of the equations $E_{d y s}=f\left(\sigma_{c r}\right)$ (Tables 2, 3; Figs. 4, 5). Similarly the value of kinetic energy accumulated in a volume unit of $\operatorname{coals}\left(E_{k}\right)$ was calculated with equation (2), defining also the form of equations $E_{k}=f\left(\sigma_{c r}\right)$ (Tables 2, 3; Figs. 4, 5).

The obtained test data enabled determining dependences between energy of deformation of coal, and uniaxial compression strength. Interpretation of the dependences discussed was limited to Upper Silesian Sandstone Series (Rudzkie Beds and Siodłowe Beds) and Paralic Series (Porębskie Beds and Jaklowieckie Beds) (Fig. 5 and Fig. 6).

Coals of Upper Silesian Sandstone Series of mean values of uniaxial compression strength between 14.0 and $52.8 \mathrm{MPa}$, reach mean values of dissipated energy between 167.150 and $780.791 \mathrm{~kJ} / \mathrm{m}^{3}$, kinetic energy between 7.685 and $447.871 \mathrm{~kJ} / \mathrm{m}^{3}$ and recoverable energy between 0.000 and $11.450 \mathrm{~kJ} / \mathrm{m}^{3}$. With an increase in uniaxial compression strength there is an increase in dissipated energy (Fig. 4). Similar relations are observed between uniaxial 
Table 1. Values of specific energy of deformation of tested lithotypes of hard coals

\begin{tabular}{|c|c|c|c|c|}
\hline \multirow{2}{*}{$\begin{array}{l}\text { Lithostratigraphic } \\
\text { Series/Beds }\end{array}$} & \multirow{2}{*}{$\begin{array}{c}\text { Uniaxial } \\
\text { compression } \\
\text { strength, MPa }\end{array}$} & \multicolumn{3}{|c|}{ Specific energy of deformation, $\mathrm{kJ} / \mathrm{m}^{3}$} \\
\hline & & $\begin{array}{l}\text { Dissipated } \\
\text { energy }\end{array}$ & $\begin{array}{l}\text { Kinetic } \\
\text { energy }\end{array}$ & $\begin{array}{c}\text { Recoverable } \\
\text { energy }\end{array}$ \\
\hline \multicolumn{5}{|c|}{ Clarain } \\
\hline $\begin{array}{l}\text { Upper Silesian Sandstone Series/ } \\
\text { Rudzkie Beds and Siodłowe Beds }\end{array}$ & $16.7 \div 32.2$ & $171.428 \div 430.580$ & $7.685 \div 115.866$ & $0.000 \div 1.302$ \\
\hline $\begin{array}{l}\text { Paralic Series/ } \\
\text { Porębskie Bedsand Jaklowieckie Beds }\end{array}$ & $2.9 \div 10.8$ & $55.310 \div 132.500$ & $0.000 \div 65.500$ & $0.570 \div 8.500$ \\
\hline \multicolumn{5}{|c|}{ Vitrain } \\
\hline $\begin{array}{l}\text { Upper Silesian Sandstone Series/ } \\
\text { Rudzkie Beds and Siodłowe Beds }\end{array}$ & $14.0 \div 43.2$ & $167.150 \div 527.500$ & $17.000 \div 419.740$ & $0.000 \div 11.450$ \\
\hline $\begin{array}{l}\text { Paralic Series/ } \\
\text { Porębskie Beds and Jaklowieckie Beds }\end{array}$ & $10.2 \div 26.3$ & $190.850 \div 337.250$ & $0.000 \div 119.583$ & $0.055 \div 4.714$ \\
\hline \multicolumn{5}{|c|}{ Durain } \\
\hline $\begin{array}{l}\text { Upper Silesian Sandstone Series/ } \\
\text { Rudzkie Beds and Siodłowe Beds }\end{array}$ & $31.6 \div 52.8$ & $442.238 \div 780.791$ & $150.984 \div 447.871$ & $0.000 \div 4.125$ \\
\hline $\begin{array}{l}\text { Paralic Series/ } \\
\text { Porębskie Beds and Jaklowieckie Beds }\end{array}$ & 40.9 & 455.460 & 270.975 & 0.000 \\
\hline
\end{tabular}

Table 2. Equations of dependences of dissipated energy and kinetic energy on uniaxial compression strength of GZW hard coals

\begin{tabular}{|l|c|c|}
\hline \multirow{2}{*}{$\begin{array}{c}\text { Lithostratigraphic Series/ } \\
\text { Seam Beds }\end{array}$} & $\begin{array}{c}\text { Dissipated energy, } \\
\mathrm{kJ} / \mathrm{m}^{3}\end{array}$ & $\begin{array}{c}\text { Kinetic energy, } \\
\mathrm{kJ} / \mathrm{m}^{3}\end{array}$ \\
\cline { 2 - 3 } & $\begin{array}{c}\text { Form of equation/ } \\
\text { correlation coefficient }\end{array}$ & $\begin{array}{c}\text { Form of equation/ } \\
\text { correlation coefficient }\end{array}$ \\
\hline $\begin{array}{l}\text { Upper Silesian Sandstone Series/ } \\
\text { Rudzkie Beds and Siodłowe Beds } \\
\text { (Fig. 4) }\end{array}$ & $\begin{array}{c}E_{d y s}=13.084 \sigma_{c r}-17.95 \\
r=0.95\end{array}$ & $\begin{array}{c}E_{k}=10.901 \sigma_{c r}-164.75 \\
r=0.94\end{array}$ \\
\hline $\begin{array}{l}\text { Paralic Series/Porębskie Beds } \\
\text { and Jaklowieckie Beds (Fig. 5) }\end{array}$ & $\begin{array}{c}E_{d y s}=9.683 \sigma_{c r}+57.53 \\
r=0.90\end{array}$ & $\begin{array}{c}E_{k}=6.387 \sigma_{c r}-54.29 \\
r=0.88\end{array}$ \\
\hline
\end{tabular}

compression strength and kinetic energy. Low mean values of recoverable energy did not show correlation with uniaxial compression strength.

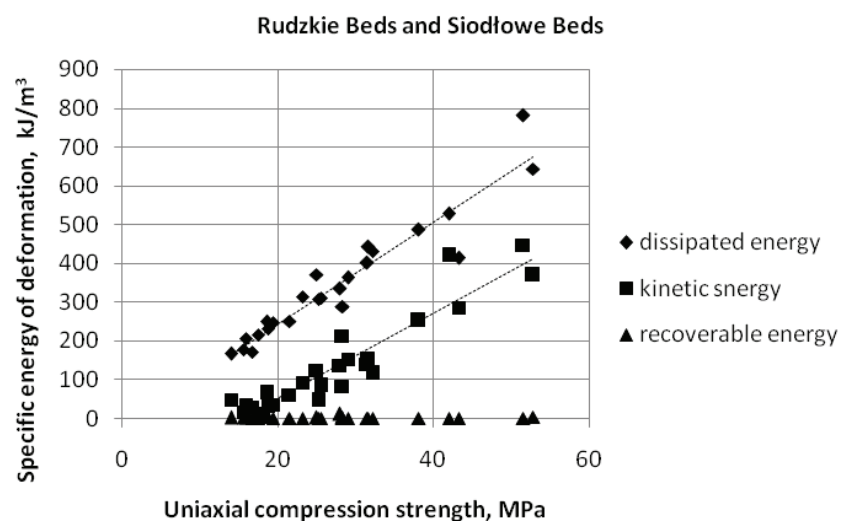

Fig. 4. Dependence of energy of deformation of Upper Silesian Sandstone Series coal on uniaxial compression strength

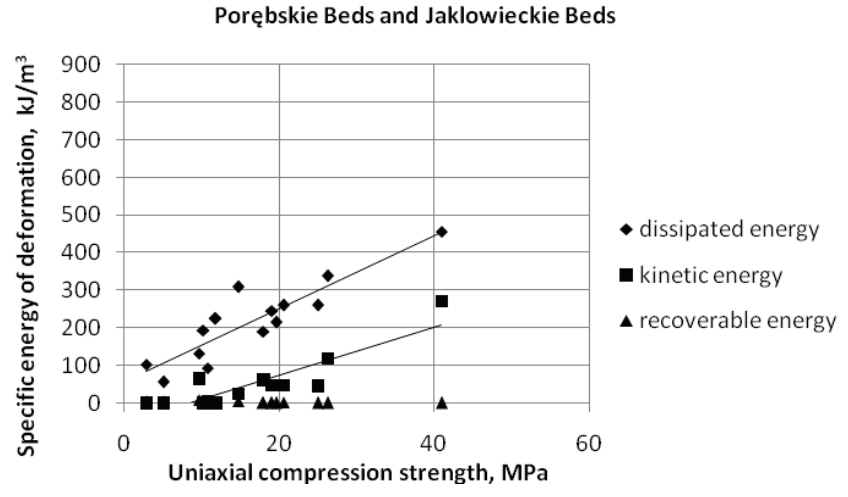

Fig. 5. Dependence of energy of deformation of Paralic Series coal on uniaxial compression strength

Mean uniaxial compression strength of coals of Paralic Series is between 2.9 and $40.9 \mathrm{MPa}$. According to Table 1 the obtained mean values of dissipated energy are between 55.310 and $455.460 \mathrm{~kJ} / \mathrm{m}^{3}$, kinetic 
energy between 0.00 and $270.975 \mathrm{~kJ} / \mathrm{m}^{3}$, and recoverable energy between 0.00 and $8.500 \mathrm{~kJ} / \mathrm{m}^{3}$. An increase in compression strength is followed by an increase in both dissipated energy and kinetic energy of Paralic Series coals (Fig. 5).

Low mean values of recoverable energy of Paralic Series coals are not correlated with uniaxial compression strength.

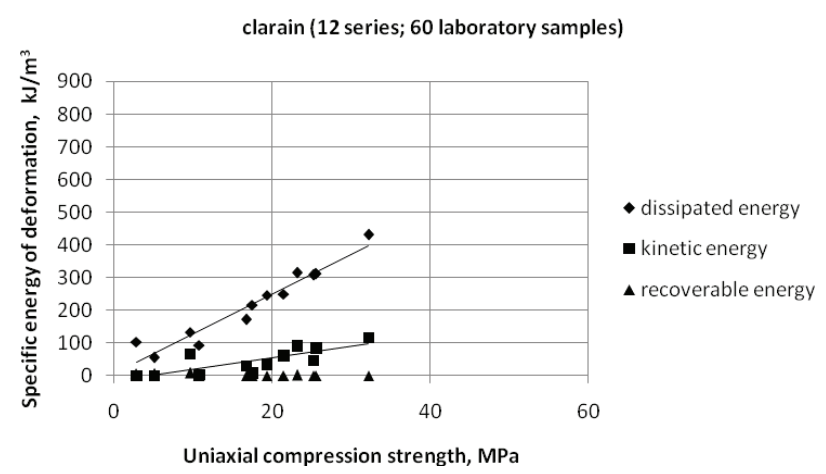

Fig. 6. Dependence of energy of deformation of clarain on uniaxial compression strength

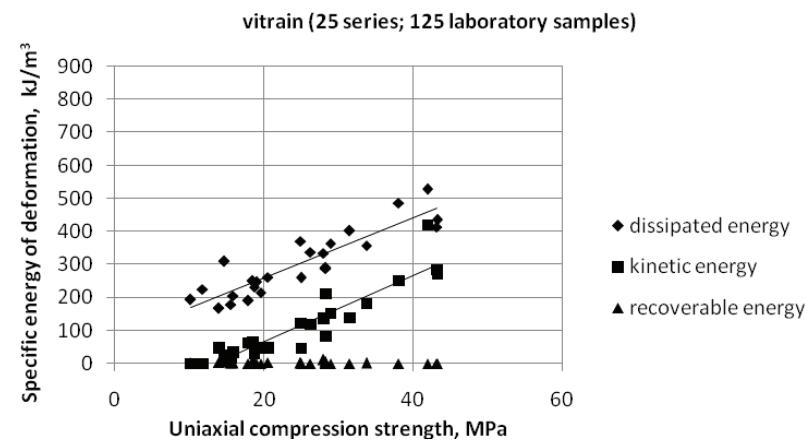

Fig. 7. Dependence of energy of deformation of vitrain on uniaxial compression strength

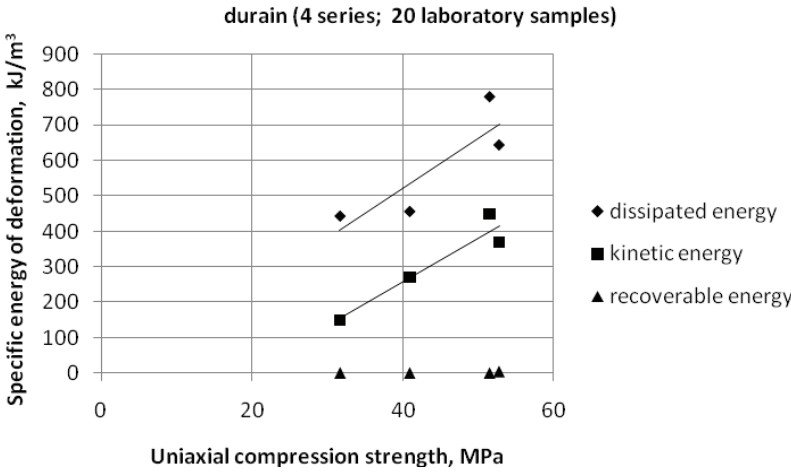

Fig. 8. Dependence of energy of deformation of durain on uniaxial compression strength

Figures 6-8 show dependence of specific energy of deformation for given lithotypes of coals on uniaxial compression strength. The tests showed, for clarain, vitrain and durain, an increase in the value of dissipated energy and kinetic energy which follow an increase in the value of uniaxial compression strength. No dependence of recoverable energy on compression strength was observed (Fig. 9).

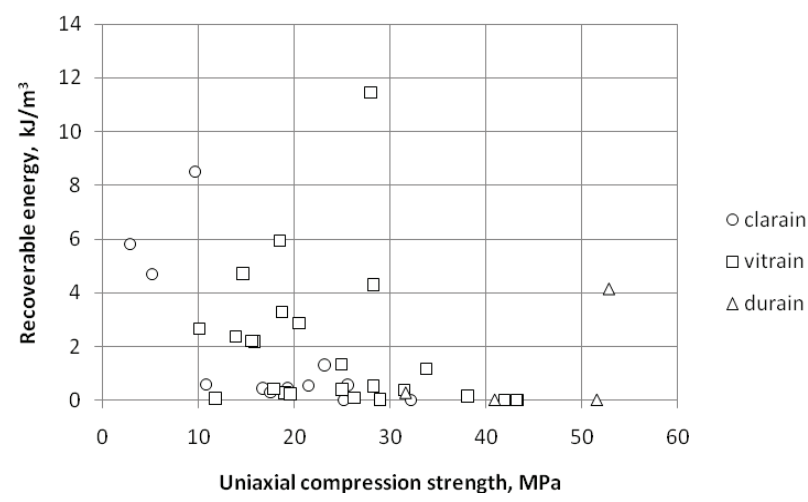

Fig. 9. Dependence of recoverable energy on uniaxial compression strength of hard coals

The form of dependence of dissipated energy and kinetic energy of the tested coals on uniaxial compression strength is presented in Table 3 .

Table 3. Equations of dependence of dissipated energy and kinetic energy on uniaxial compression strength for given lithotypes of GZW hard coals

\begin{tabular}{|c|c|c|}
\hline \multirow{2}{*}{$\begin{array}{c}\text { Linotype } \\
\text { of coal }\end{array}$} & $\begin{array}{c}\text { Dissipated energy, } \\
\mathrm{kJ} / \mathrm{m}^{3}\end{array}$ & $\begin{array}{c}\text { Kinetic energy, } \\
\mathrm{kJ} / \mathrm{m}^{3}\end{array}$ \\
\cline { 2 - 3 } & $\begin{array}{c}\text { Form of equation/ } \\
\text { correlation coefficient }\end{array}$ & $\begin{array}{c}\text { Form of equation/ } \\
\text { correlation coefficient }\end{array}$ \\
\hline $\begin{array}{c}\text { Clarain } \\
\text { (Fig. 6) }\end{array}$ & $\begin{array}{c}E_{d y s}=12.142 \sigma_{c r}+7.34 \\
r=0.96\end{array}$ & $\begin{array}{c}E_{k}=3.486 \sigma_{c r}-15.84 \\
r=0.79\end{array}$ \\
\hline Vitrain & $E_{d y s}=9.028 \sigma_{c r}+78.07$ & $E_{k}=9.968 \sigma_{c r}-132.53$ \\
(Fig. 7) & $r=0.90$ & $r=0.92$ \\
\hline $\begin{array}{c}\text { Durain } \\
\text { (Fig. 8) }\end{array}$ & $\begin{array}{c}E_{d y s}=14.046 \sigma_{c r}-40.58 \\
r=0.86\end{array}$ & $\begin{array}{c}E_{k}=12.303 \sigma_{c r}-234.32 \\
r=0.95\end{array}$ \\
\hline
\end{tabular}

An important result of the tests is showing changes in percentage share of given specific energy of deformation of coal in the total energy of Upper Silesian Sandstone Series and Paralic Series depending on uniaxial compression strength. The tests showed that at the level of the lowest values of uniaxial compression strength, characteristic of clarain, dissipated energy has a dominant share in the total energy, in spite of the fact that the share of recoverable energy of a few per cent is then the highest. Following an increase in the value of uniaxial compression strength the percentage share of recoverable energy in the total energy decreases. 


\section{SUMMARY}

The process of destroying a rock sample in laboratory conditions during a test of compression is presented in stress-strain characteristics. Based on the course of the characteristics discussed, values of energy parameters are obtained. The article presents state-of-art research conducted at the Central Mining Institute concerning specific energy of longitudinal strain of rocks of elasto-plastic properties with softening.

Determining relations between the obtained values of specific energy of longitudinal deformation, and uniaxial compression strength enabled formulating the following conclusions:

- An increase in dissipated energy and kinetic energy following an increase in uniaxial compression strength of coal was observed in all three lithotypes of hard coal and for coals of the tested seams of Upper Silesian Sandstone Series and Paralic Series and various geologic units of GZW. The dependence was described with a linear function.

- Considering percentage share of dissipated energy and recoverable energy as components of the total specific energy of longitudinal strain it was shown that dissipated energy is the dominant one. In coals of low strength and the dominant share of dissipated energy, the share of recoverable energy is the highest among the tested coals. Following an increase in the value of uniaxial compression strength the percentage share of recoverable energy decreases in favour of dissipated energy.

Values of particular specific energy of longitudinal strain of coals and determining functional dependences between geomechanical and energy parameters will enable applying them to solve various problems of underground mining, especially in assessing occurrence of certain natural hazards, e.g., rock burst hazard considering the natural rock burst susceptibility of rock mass and changes in the susceptibility resulting from the mining activities.

\section{REFERENCES}

[1] Bieniawski Z.T., Time-dependent behaviour of fractured rock, Rock Mechanics, 1970, Vol. 2, 3, 123-137.

[2] Bukowska M., Mechanical properties of carboniferous rocks in the Upper Silesian Coal Basin under uniaxial and triaxial compression tests, Journal of Mining Science, 2005, 41, No. 2, 129-133.
[3] Bukowska M., Prognozowanie skłonności do tapań górotworu metoda wskaźnikowej oceny geologiczno-geomechanicznej w warunkach Górnoślaskiego Zagłębia Węglowego (Forecasting rock burst susceptibility of rock mass with index assessment method in Upper Silesian Coal Basin), Prace Naukowe GIG, 2005, nr 866.

[4] BukowsKa M., (red.), Kompleksowa metoda oceny sktonności do tapań górotworu $w$ Górnoślaskim Zagłębiu Weglowym (Complex method of assessing rock burst susceptibility of rock mass in Upper Silesian Coal Basin), Wyd. GIG, Katowice 2009.

[5] BUKOwSKA M., Skłonność górotworu do tapań - geologiczne i geomechaniczne metody badań (Rock burst susceptibility of rock mass - geological and geomechanical test methods), Główny Instytut Górnictwa, Katowice 2012.

[6] GustKIEwicz J. et al., Wpływ wody na mechaniczne właściwości skat tapiacych (Influence of water on mechanical properties of bursting rocks), Sprawozdanie etapowe, Instytut Mechaniki Górotworu PAN, Kraków 1987.

[7] GuSTKIEwICZ J. et al., Właściwości fizyczne wybranych skat karbońskich Górnoślaskiego Zagtębia Węglowego. Skaty warstw siodtowych (Physical properties of selected carboniferous rocks of Upper Silesia Coal Basin. Anticline Beds rocks), IGSMiE PAN, Kraków 1999.

[8] FILCEK H., Rola pozniszczeniowej charakterystyki naprężeniowo-odksztatceniowej skat $w$ zagadnieniu tapań (Role of post-failure recoverable energy characteristics of rocks in rock bursts), Górnictwo, 1986, Vol. 2, 177-184.

[9] Heasley K.A., An examination of energy calculations applied to coal bump prediction, Rock Mechanics as a Multidisciplinary Science, Balkema, Rotterdam, 1991, 481-490.

[10] Hudson J.A., Brown E.T., FAirhurst C., Shape of the complete recoverable energy curve for rock, Proc. 13th Symp. Rock Mech., Illinois, 1971, 773-795.

[11] Labuz J.F., Biolzi L., Class I vs class II Stability: A demonstration of size effect, Int. J. Rock Mech. Min. Sci. \& Geomech. Abstr., 1991, Vol. 28, No. 2/3, 199-205.

[12] Krzysztoń D., Wosz R., CieŚlik J., KLISOwsKi R., Określenie skłonności skat do tapań na podstawie badań próbek skalnych z kopalń Peru w sztywnej maszynie wytrzymałościowej, Górnictwo i Geoinżynieria, 2008, 32/4, 23-39.

[13] KWAŚNIEWSKI M., Zachowanie się rocks izo- $i$ anizotropowych $w$ warunkach trójosiowego ściskania (Behaviour of iso- and anisotropic rocks under triaxial compression), Wydawnictwo Politechniki Śląskiej, Gliwice 2002.

[14] Merwe J.N., A laboratory investigation into the effect of specimen size on the strength of coal samples from different areas, J. S. Afr. Inst. Mining Metal, 2003, Vol. 103, No. 5, 273-279.

[15] Peng S.S., Time-dependent aspects of rock behaviour as measured by servo controlled hydraulic testing machine, Int. J. Rock Mech. Min. Sci., 1973, 3.

[16] UluSAY R., HudSON J.A. (eds.), The complete ISRM suggested methods for rock characterization, testing and monitoring: 1974-2006, Commission on testing methods ISRM, 2007.

[17] XIE H.P., Li L., Peng R.D., Ju Y., Energy analysis and criteria for structural failure of rocks, Journal of Rock Mechanics and Geotechnical Engineering, CSRME, Journal online, 2009. 